\title{
Does International Student Exchange Contribute to Educating Teachers We Need in a Multicultural Society?
}

\section{Keywords:}

student exchange internationalization teacher education teachers

multicultural society. 


\section{Abstract}

The purpose of this article is to present a study of some student teachers' outcome of their international exchange, focusing on multiculturalism and the students' intercultural education. The article is based on a quantitative study over three academic years. The study is a survey of the students' knowledge, thoughts, and feelings before and after their stay abroad. Most of the answers to the questions in the survey are consistent from one year to the next, and there is no significant difference from one country to another. Consequently, the results may apply to any teacher-training institution. According to the data from the study, the benefits derived from student exchange are numerous and contribute to forming the teachers we need in a multicultural society. 


\section{Introduction}

Much attention has been paid to and pages have been written about the benefits gained from the internationalization of higher education. The literature recognizes that higher education is very important when facing challenges such as democracy, equal opportunity, shared values, prosperity for all, solidarity, and cooperation (Chovancová, 2007; Maiworm \& Teichler, 1996; Paige, Cohen, Kappeler, Chi, \& Lassgard, 2002; Papatsiba, 2005; Teekens, 2006; Teichler \& Maiworm, 1997).

International organizations have developed recommendations concerning education in order to strengthen international understanding of human rights, international cooperation and understanding, and education for peace. The growth of internationalization in higher education is partly a result of following two documents: The World Declaration on Higher Education in the Twenty-First Century (UNESCO, 1998), and the Bologna Declaration (1999).

Does international student exchange contribute to strengthening of international understanding of human rights, strengthening of international understanding and cooperation, as well as education for solidarity, democracy, and peace? These questions and challenges are important for international student exchange. They have been the subject of an extensive multidisciplinary literature and have also given rise to a number of community directives and recommendations intended to facilitate the internationalization of higher education (UNESCO, 2000; European Commission, 1995; Europa. Summaries of EU legislation, 2009; European Commission. Education \& Training, 2013a, 2013b). Thus, an important question for professors and administrative staff involved in student teacher exchange is: what is the exchange students' outcome of their stay abroad?

In 2007, a discussion on the issues of the quality of Erasmus exchanges took place in an Erasmus teacher-training network meeting. It led to the formation of a group of four experienced international academic coordinators. The purpose of the group was to evaluate the practice within the network of the Erasmus Exchange Programme.

The data were collected over a period of three years, from $2008-2011$ and used in an article were the main objective was to evaluate student teachers' outcome of their international exchange, evaluate the practice of the program within the institutions of the network, and initiate a process of quality assurance for the institutions, the international coordinators, and the students (Berg, 2014).

The study produced much data in order to answer all our questions. One important conclusion was that the students ranged personal development and benefits as the most important outcome of their study abroad.

It would be of interest to learn more from these data and consider more closely the data about the students' personal development. Hence, the present article is based on the quantitative data concerning the students' personal development from the study described above. In the discussion part of the article, the data from the current study will be presented and juxtaposed with some qualitative data from other student exchange evaluations, since our study did not include qualitative data.

The purpose of this article is to focus on the students' evaluation of their multicultural experiences and intercultural development during their exchange period. The article aims at giving an answer to the following research question: Does international student exchange contribute to educating the teachers we need in a multicultural society?

The definitions of multiculturalism and multicultural society in this article are mainly based on the theory of Bhikhu Parekh from his book Rethinking Multiculturalism (Parekh, 2002), on Samovar, Porter and MacDaniel's book Communications between Cultures (Samovar, Porter, \& McDaniel, 2010), and on Meer and Modood's How Does Interculturalism Contrast with Multiculturalism? (Meer \& Modood, 2012). The definitions of intercultural competence 
and intercultural development are in accordance with those of Landis \& Bennett (2004) and Dahl, Habert, \& Dybvig (2001).

The concept of multiculturalism as opposed to interculturalism, has given rise to an extensive debate. To go into this debate is beyond the scope of this article. Here, the term multicultural is used for multicultural society, multicultural experience, multicultural network, and multicultural understanding. To have a multicultural understanding is indispensable for developing an intercultural dialogue. Thus, in this article, intercultural is applied to concepts of a more dialogical or developing character, such as intercultural education, intercultural communication, intercultural dialogue, intercultural development, and intercultural competence.

In his book Rethinking Multiculturalism, Bhikhu Parekh (2002), defines multiculturalism and multicultural society thus:

Multiculturalism is about the proper term of relationship between different cultural communities. The norms governing their respective claims, including the principle of justice, cannot be derived from one culture alone but through an open and equal dialogue between them [...] By definition a multicultural society consists of several cultures or cultural communities with their own distinct system of meaning and significance and views on man and the world (Parekh, 2002, p. 13).

According to Parekh, a multicultural society cannot be stable and last long without developing a common sense of belonging among its citizens. Parekh's theory of multiculturalism is dialogic and states that a multicultural society necessitates an institutionalization of intercultural dialogue and that the proper way of responding to cultural and religious diversity is to initiate and create an equal dialogue between the different cultures.

It is therefore important for teachers in a multicultural society to possess intercultural competence. Intercultural competence is in this article defined, in accordance with Landis, D., \& Bennett, J. M. (2004), as an increasing ability to shift perspective, cognitively and behaviorally, to another culture. This is in line with Dahl et al. (2001), who define intercultural competence as "the ability to communicate adequately and appropriately in a given situation in relation to people with different cultural preconditions" (Dahl et al., 2001, p. 203 as cited in Hoaas, (2014)).

\section{Method}

The research group ${ }^{1}$ started their work in 2007 by organizing a workshop among the members of the network to formulate research questions for a pilot project. The workshop generated research questions such as these: Who are the students who go abroad? What are their motives for going abroad? For what reasons do they choose the particular host university? How do they get information about the exchange program? Are they worried before leaving? Are they concerned about practical problems like money and accommodation? What are the most important achievements of the exchange? What are the students' most positive and negative experiences? What is important for the students academic achievements or social experiences, better multicultural understanding, and intercultural development? What do they consider the most important outcome of their exchange - the academic achievements or the cultural and social experiences?

To answer the questions, the research group decided to carry out a quantitative research. Two questionnaires form the basis of the inquiry. Questionnaire 1 is to be filled in by the

\footnotetext{
${ }^{1}$ The members of the group, in alphabetical order, are Vera Berg, Oslo and Akershus University College of Applied Sciences, Norway, Teresa Grange, Université de la Vallée d'Aoste, Italy, Soledad Guardia González, Universidad Complutense Madrid, Spain, and Dominique Trumel, Université de Cergy-Pontoise, France.
} 
students before departure, and questionnaire 2 is to be filled in by the same students after returning. After a pilot project in 2007, only some minor linguistic adjustments in the questionnaires were made. The questionnaires are organized so that we can compare the answers from the students before they leave and when they return.

Questionnaire 1 includes 35 questions intended to identify the following:

- Who are the students going abroad?

- What are the students' motives for going abroad?

- For what reasons do they choose the host university?

- Do they have any international experience before leaving?

Questionnaire 2 includes 22 questions intended to reveal the following:

- What is the students' evaluation of the benefits of their international exchange as a whole?

- Did the students achieve their objectives?

- What are the students' most important benefits of the exchange?

The two questionnaires include closed questions and multiple-choice Likert-scale items intended to identify the knowledge, expectations, opinions, thoughts, feelings, and attitudes of the students (Likert, 1932).

The data were collected over a period of three academic years from 2008 to 2009, from 2009 to 2010, and from 2010 to 2011. We surveyed 354 participating students from 11 different higher education institutions in 11 European countries. The students who participated in Erasmus exchange were sent to more than 60 European higher-education institutions.

The research was made possible because the members of the Erasmus network had initiated the study and were willing to distribute questionnaires to their students and send the completed questionnaires back to the research group. As a result, the response rate is almost $100 \%$.

The data of the survey were analyzed in the SPSS program to obtain a descriptive analysis of results. The program provides a description of students' experiences and a comparison between their answers before and after their stay abroad.

The research group had planned to follow up some of the students with interviews after having analyzed the quantitative data. We assumed it would be necessary to do a more indepth study of certain questions and issues from the survey. Unfortunately, we were hit by the "Euro crisis," so it was not possible for us to accomplish this part of the study due to the lack of funding.

The present article is based on a selection of the quantitative data from the 2008-2011 survey and is supplemented with the qualitative data from other sources. The most significant findings are illustrated by the quotations taken from the interviews with the students or the groups of students after their exchange programme had finished, as reported in other studies. Thus, both quantitative and qualitative methods for the triangulation of the data are used to answer the research question 


\section{Results and Discussion of Findings}

The survey has produced a considerable amount of data. Firstly, I will provide a brief overview of the exchange students' characteristics. The results are then discussed with respect to the subject of this article and the research question. The focus is made on the students' overall evaluation of the exchange program, their motives for going abroad, their feeling of belonging to a larger community, and development of intercultural competence and self-confidence.

It is remarkable that most of the answers to the questions asked in the questionnaires are consistent from one year to the next, and that there are no significant differences from country to country. Hence, the results of this survey might also apply to other teachertraining institutions than those participating in the survey.

\section{The Students' Personal Data}

The typical exchange student in the survey is female, single, and between 21 and 25 years old $(81 \%$ of the exchange students in the study were females). She has more than average experience of travelling abroad. More than $90 \%$ of the students had been abroad before the exchange period. Their main motives for travelling before the exchange had been tourism and leisure, although about $30 \%$ of them had been abroad for language studies. Most of them were studying to become primary-school teachers or early-childhood teachers. The students were all in the second or third year of their bachelor degree study, about $50 \%$ from each year.

\section{The Students' Overall Evaluation of Their Exchange Period}

Like many other studies evaluating various aspects of international exchange programs (e.g. Cervelló Collazos \& Guardia González, 2008; Alfranseder, Fellinger, \& Taivere, 2011; Maiworm \& Teichler, 1996), this study shows that the students are very satisfied. The benefits obtained from international exchange are numerous. In questionnaire 2 after returning from the exchange period, the students were asked "How do you evaluate the program as a whole?" and "Did your participation in the Erasmus Programme enable you to achieve your objectives?". Figure 1 shows that the overall evaluation is very positive. A little more than $80 \%$ on average over the three years considered the program as good or very good, and as can be seen in Figure 2, most of the students (more than $77 \%$ on average over the three years) stated that the program enabled them to achieve their objectives. 
Figure 1

"How do you evaluate the program as a whole?"

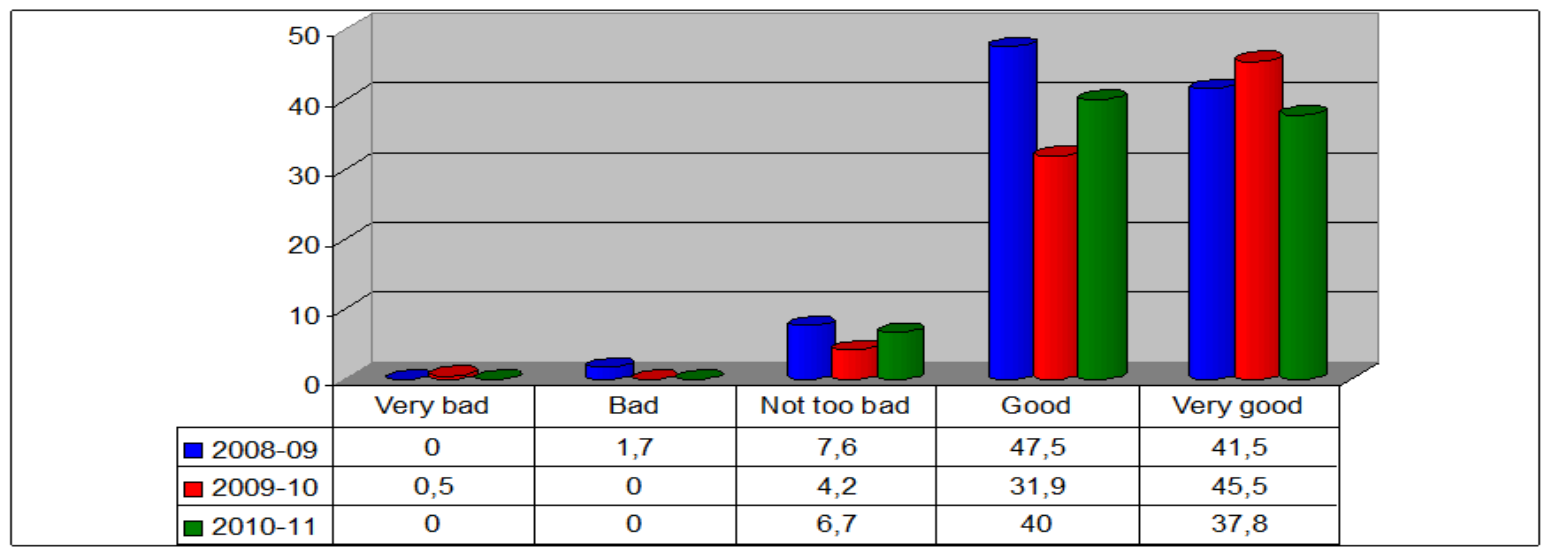

Figure 2

"Did your participation in The Erasmus Programme enable you to achieve your objectives?"

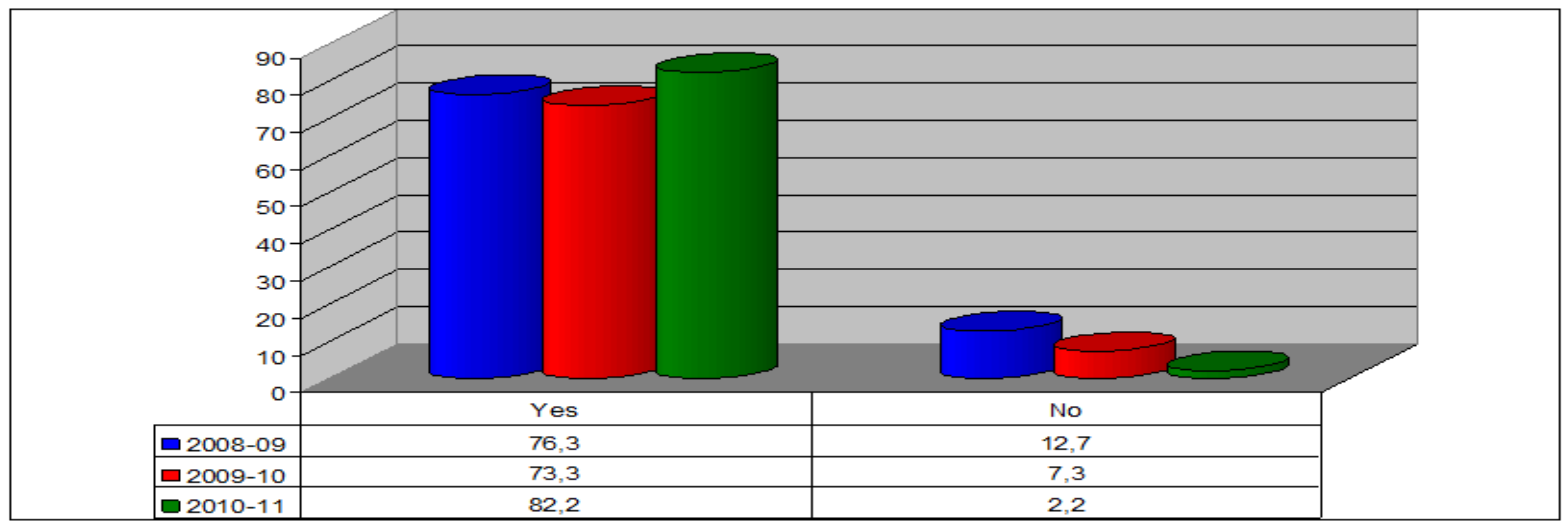

The Students' Motives for Going Abroad

Before leaving, the students were asked to complete Questionnaire 1, detailing their motives for going abroad and asked to rate nineteen pre-defined motives with regard to their importance on a scale from 1 (not important) to 4 (most important). According to the students' priorities, the five most important motives are the following, and they are all rated higher than three on a scale of four:

1. To improve knowledge of languages $(3,68)$

2. To visit a foreign country $(3,58)$

3. To learn about another culture $(3,50)$

4. To develop personally $(3,50)$

5. To experience life in a new environment $(3,35)$ 
It is remarkable that the students' motives mainly concern the acquisition of foreign languages and intercultural competence. The students rated as less important academic and pedagogical motives like "to learn about different didactic methods" and "to benefit from higher quality of the study program abroad."

Upon returning, according to their answers to questionnaire 2, the students confirm the importance of the motives above and add the following new motives as very important outcomes of their stay abroad, all rated higher than three on a scale of four:

- Cultural and social experiences $(3,67)$

- Better multicultural understanding $(3,63)$

- New foreign friends $(3,61)$

- Better knowledge of the country they visited $(3,41)$

We notice once again that motives related to intercultural competence and multicultural experiences are very important to the students and seem to be more relevant to them than academic, pedagogical, and professional aspects. This is in line with many other studies evaluating various aspects of exchange programs (Alfranseder et al., 2011; Maiworm \& Teichler, 1996; Teichler \& Maiworm, 1997).

\section{The Students' Feeling of Belonging to a Larger Community}

Since this study was originally a study of the Erasmus exchange and partly funded by Erasmus grants, the students were in questionnaire 1 (before they went abroad) asked about their feelings of "being European" (of European citizenship).

Figure 3

"Do you feel European?"

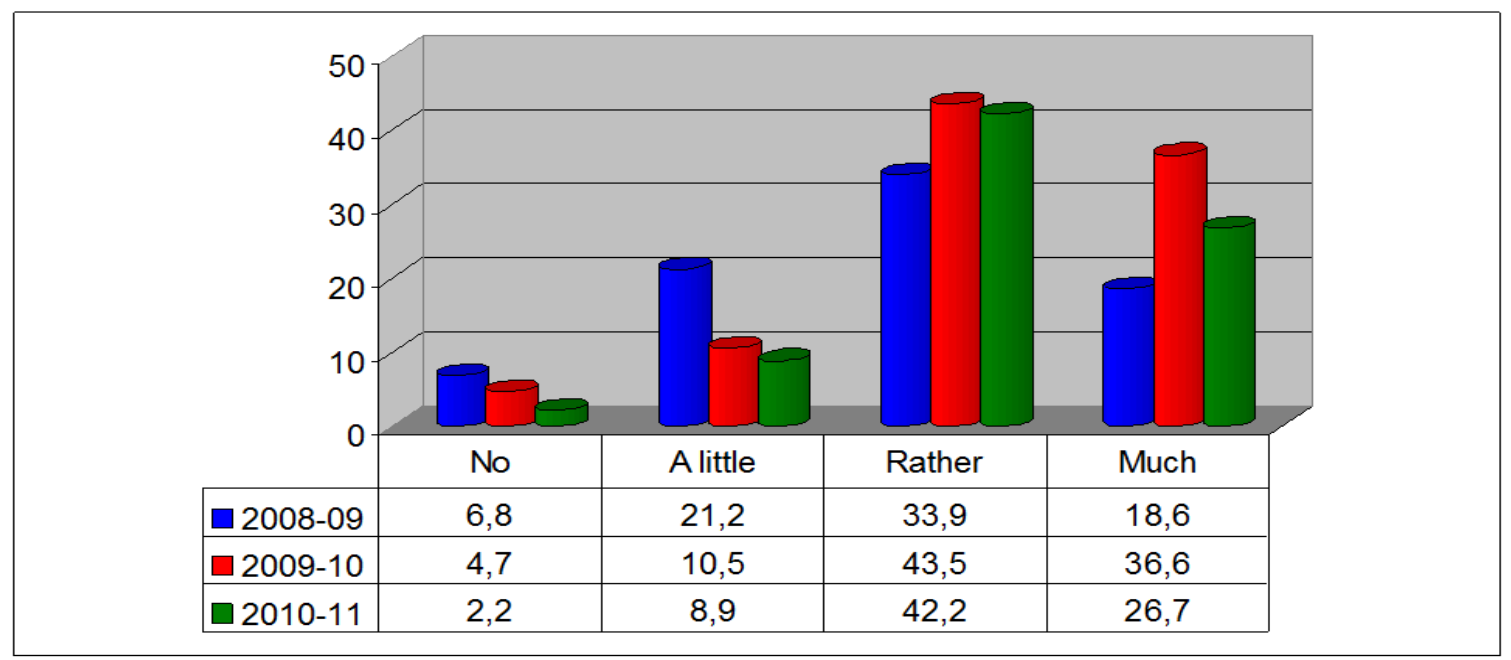

As can be seen from Figure 3,67\% of the students, on average over the three years, feel "rather" or "much" European before leaving. It may be surprising that before leaving, so many of the students feel European. One reason may be that the students in the study had more than average experience of travelling abroad. 
Figure 4

"Has your participation in the Erasmus Programme made you feel more European?"

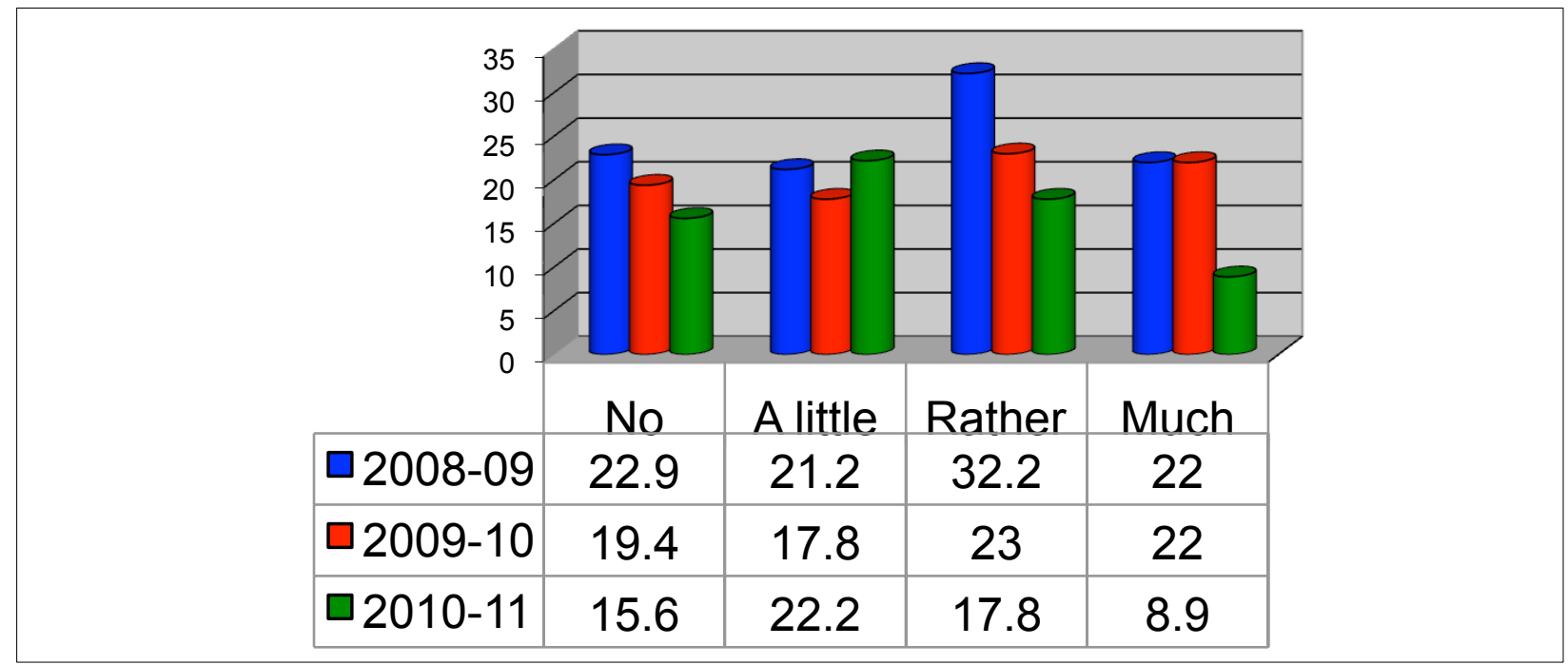

Upon returning, in questionnaire 2, the students were asked if the stay abroad made them feel "more European." Even though a majority of them felt European before leaving, a great deal of them ( $62 \%$ as an average over the three years, as can be seen in Figure 4 ), have increased their feeling of European citizenship while being abroad. It may be mentioned that there are no differences between the Norwegian students (non-EU members) and the students from EU countries.

Figure 5

"Has your participation in the exchange program encouraged you to work abroad?"

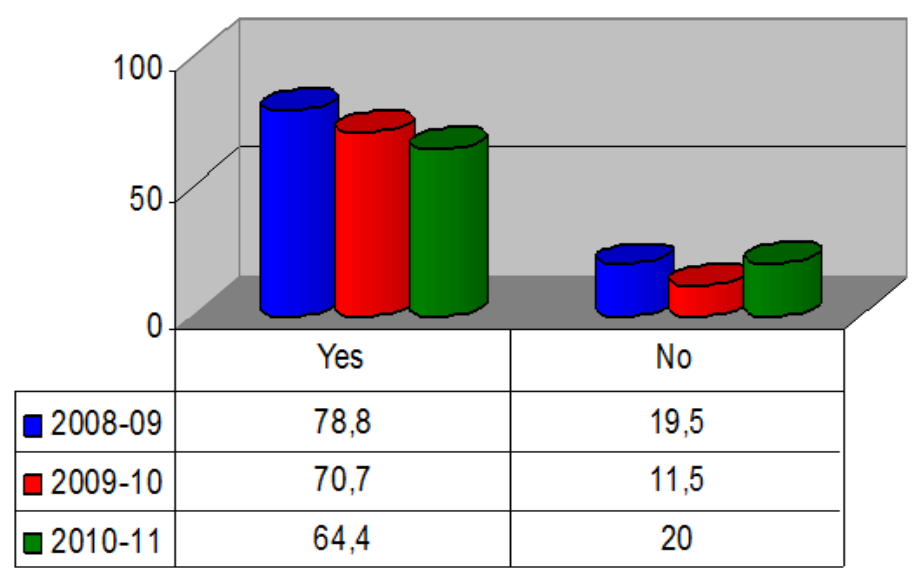


Figure 5 shows that the participation in the exchange program encourages most of the students to work abroad in the future. $72 \%$ of the students on average over the three years, stated that the participation in the exchange program had encouraged them to work abroad in the future. This result may indicate that taking part in an exchange program contributes to making the students more open-minded and internationally orientated, a result similar to that discovered in other studies (Alfranseder et al., 2011; Maiworm \& Teichler, 1996; Teichler \& Maiworm, 1997), and in line with The Erasmus Lifelong Learning Programme (Europa. Summaries of EU legislation, 2009).

\section{Improving Intercultural Competence and Self-Confidence}

As shown in Figure 6, almost all the students reported that they were anxious before they left home.

Figure 6

"Are you anxious before leaving?"

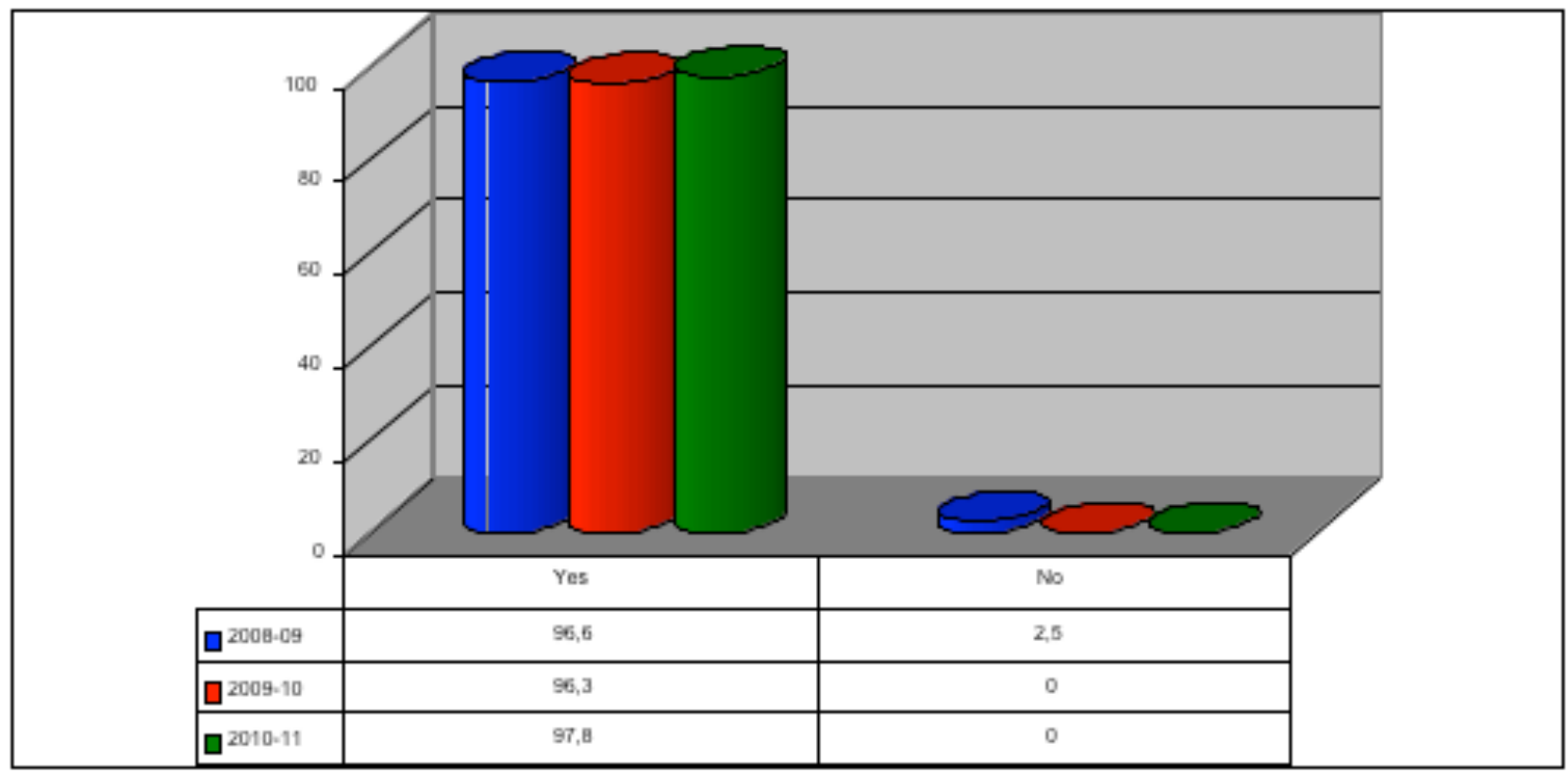

What they were worried about were multicultural and intercultural problems, mostly language-related, such as facing problems with the language of instruction, having problems with the language of the university (these two are not necessarily the same), or having problems with the language of the host country. They were also worried about not being able to communicate with the pupils in the schools during the students' teaching practice. Other problems they feared were not being able to adapt to the customs of the host country or to the educational institution.

Nevertheless, after the exchange, they do not report significant problems. Therefore, it is likely that the students improved their self-confidence, their multicultural understanding, and their intercultural competence because of challenges encountered and problems they were able to solve. This is a very important experience for a future teacher.

Eriksen (2006) interviewed 10 exchange students from Oslo University College (Norway) who participated in school practice in Ecuador, Indonesia, Kenya, Namibia, Serbia and Sweden on two occasions: the first time after their return back home from abroad and the 
second time at the end of their studies. Her data provide examples of the students' opinions on the outcomes of the school practice abroad. One of the students in Eriksen's study expresses her experiences as follows:

To live alone in another culture, to make decisions far from family and friends, has given my life and education new social and cultural perspectives. (Eriksen, 2006, p. 50).

Only about $50 \%$ of the student teachers in the survey got some teaching practice abroad, contrary to what is recommended in ERASMUS Subject Evaluations, stressing the importance of some sort of practice for the student teachers (European Commission, 1995).

School practice abroad should be important for the exchange student teachers' intercultural development. Another student teacher from Oslo University College puts it like this in an interview conducted by Eriksen (2006, p.49):

It has been important for me to teach in a different culture with different curriculum and under different conditions. I have learnt that teaching is much more than I believed when I was in school practice in Oslo. I have used another language that [sic] Norwegian and experienced that it is not always so easy to be in a minority group without perfect language competence. These experiences have opened my eyes for what kind of difficulties minorities in Oslo might have in school.

To be an exchange student is also important in building an international network because the students find friends from all over the world. Through their new friends and contacts, they learn about many different cultures. At the same time, they get new insights into their own country, viewing it from a new angle when being abroad.

In a publication from European Commission on Erasmus Program (2010), a student from Ireland expresses his experience in this way:

During the five months I lived in Finland, I met people from all around Europe. My exchange with them taught me more about our continent's history than anything I had learnt in school. I was stunned by how many languages my fellow Erasmus students spoke. (European Commission, 2010, p. 23)

The following three statements are from a focus group interview with incoming Erasmus students at Universidad Complutense Madrid. The interview was completed just before the students returned (Martin, 2012; translation into English by Guardia González). The first quotation follows up what the student from Ireland said about informal and important learning during his exchange period in Finland:

Student exchange is a lot more than a studying experience. For me it is a way of looking at the world with new eyes, of feeling and discovering new emotions and learning what is not written in the textbooks.

The next quote is about personal and multicultural experiences:

I realized that the experience made me a completely new person and that I would never look at the world and Europe, my home, as I had done before.

One of the English students concludes the interview in this way:

What is certain is that the fact of being an exchange student makes us feel much closer to what is happening in other countries because like it or not, you have friends on all sides. 
The student exchange does not automatically lead to these results. We know from experience and from the literature that sometimes, the international destination may be like a background for unchanged behavior, leading to a reinforcement of previous thinking and the development of xenophobic views, the contrary of what international exchange programs for students are aiming at (Teekens, 2006).

This does not seem to be the case for the majority of the students in the present study. From the data above, we may draw the conclusion that in the students' opinion, international exchange was most important to making new friends from many counties, to the acquisition of foreign language, and to the development of better intercultural competence. Academic learning seems to be less important for the students when they decide to take part in the exchange program and when they evaluate the benefits. According to the quantitative data of the survey and the qualitative data above, it seems that the students consider informal learning during their stay abroad the most important outcome of their exchange period.

A very important objective for The Erasmus Programme is the contribution to a better multicultural world by strengthening international understanding through international education (Europa. Summaries of EU legislation, 2009). This is in line with what the famous American senator J. William Fulbright says we should try to achieve through international education.

What we must all try to acquire through education, and particularly through international education, is some degree of perception and perspective about various people in the world. (Koester, 1988, p. 121)

Fulbright does in his writings and speeches repeatedly underline the importance of international education for creating a better multicultural world, which is the same idea that we have seen in the Erasmus Life Long Learning Programme.

One of the reasons that universities support and encourage students to enter exchange programs is most likely that they believe interaction and communication with people from other cultures improve intercultural understanding, better communication skills, and enhance sensitivities and tolerance across religious and cultural boundaries.

Intercultural development is fundamental in intercultural education and training. Intercultural competence enables the students and the future teachers better to understand, adapt to, and work with people and groups that are culturally different. Intercultural development includes acquiring new skills in communication and interaction, new cultural knowledge, culture learning skills, and competence in working across cultures. Hence, intercultural competence is indispensable today and will be indispensable in the future for all teachers working in multicultural societies, which a vast majority of the teachers already do and will be doing in the future.

Summing up, the results of this study show that the students rated the exchange project as good. Almost all the students were anxious before leaving. Nevertheless, when returning, they reported not having experienced serious problems. The reasons for students to go abroad were cultural and personal rather than academic. Students' most important motives for going abroad were to improve their knowledge of languages, to visit a foreign country, to learn about another culture, and to develop personally. The less important motives were academic and pedagogical goals or problems with the study program at home. Of the outgoing students, $67 \%$ (on average over the three years) scored "high" or "rather high" on questions concerning their feeling of "being European," and after returning, about $62 \%$ stated that the Erasmus stay made them feel even more European. Of the students, $72 \%$ (on average over the three years) answered that the participation in the exchange experience had encouraged them to work abroad in the future. 
As discussed above, these results suggest that international student exchange programs have the potential to contribute to the student teachers' development of intercultural competence and self-confidence, and that such exchange programs might be important for educating the teachers we need in a multicultural society.

\section{Conclusion}

The benefits derived from the student exchange programs are numerous. The students put forward the learning of a new language, cultural experiences, social experiences, a better multi-/intercultural understanding, a better knowledge of the visited country, and a strengthening and building of an international network as being the most important benefits of their student-exchange period. All score more than three on a scale of four. This, together with the students' growing self-confidence and an increasing feeling of belonging to a larger community, indicates that taking part in an exchange program contributes to making the students more open-minded and strengthening their multicultural understanding and intercultural competence.

From the data presented in this article, we may conclude that the students have increased their linguistic skills, their multicultural network, their multicultural understanding, and their intercultural competence. After their exchange abroad, the students seem to have obtained an understanding and a feeling of belonging to a larger community and are better prepared to accept foreign cultures.

Consequently, we may conclude that international student exchange has been and will be very important in shaping the next generations of teachers and contributes to the education of the teachers and citizens we need in a multicultural society. 


\section{References}

Alfranseder, E., Fellinger, J. \& Taivere, M. (2011). E-Value-ate Your Exchange: Research Report of the ESNSurvey 2010. Retrieved from https://esn.org/ESNSurvey/2010

Bennett, M. J., Landis, D., \& Bennett, J. M. (2004). Handbook of intercultural training = Intercultural training (3rd ed.). Thousand Oaks, CA: SAGE.

http://dx.doi.org/10.4135/9781452231129.n6

http://dx.doi.org/10.4135/9781452231129.n1

http://dx.doi.org/10.4135/9781452231129.n10

Berg, V. (2014). Evaluation of the outcome of European students-teachers' participation in the Erasmus Exchange Programme (2008-2011): A survey of students' knowledge, thoughts and feelings before and after their Erasmus exchange. Journal of the European Teacher Education Network, 9, 33-45.

Bologna Declaration. (1999). The Bologna Declaration of 19 June 1999: Joint Declaration of the European Ministers of Education. Retrieved from http://www.uka.amu.edu.pl/bologna.html

Cervelló Collazos, J., \& Guardia González, S. (2008). Évaluation de la satisfaction des étudiants européens ayant participé au programme R.E.S.O. In M. J. Berger \& R. Forgette-Giroux (Eds.), Bilan et perspectives. Coopération entre I'Union européenne et le Canada dans la formation des enseignantes et des enseignants (pp. 55-67). Ottawa: Editions La Peŕichole.

Chovancová, K. (2007). Les echanges universitaires en tant que cadres de la sensibilisation interculturelle. Enseigner L'Europe, Actes de colloque international Banská Bystrica septembre 2007, 71-77.

Dahl, Ø., Habert, K., \& Dybvig, P. (2001). Møter mellom mennesker: Interkulturell kommunikasjon [Encounters between people: Intercultural communication]. Oslo: Gyldendal akademisk.

Eriksen, T. B. (2006). Internationalization in a teacher education program. Journal of the European Teacher Education Network (JETEN), 2(1), 43-53.

Europa. Summaries of EU legislation. (2009, January 29). Lifelong Learning Programme 2007-13. Retrieved from http://europa.eu/legislation summaries/education training youth/general framework

European Commission. (1995). ERASMUS Subject Evaluations. Summary Reports of the Evaluation Conferences by Subject Area. Teacher education in Europe. Retrieved from http://ec.europa.eu/education/erasmus/doc/publ/conf en.pdf

European Commission. (2010). Erasmus: I am one of the two million who did it! Luxembourg: Publications Office of the European Union. Retrieved from http://ec.europa.eu/education/tools/docs/2million en.pdf

European Commission. Education \& Training. (2013a, July 9). European personalities urge EU leaders to back Erasmus. Retrieved from http://ec.europa.eu/education/news/20121109 en.htm

European Commission. Education \& Training. (2013b, July 9). History of the ERASMUS Programme. Retrieved from http://ec.europa.eu/education/erasmus/history en.htm

García Nieto, N., Asensio Muñoz, I., Carballo Santaolalla, R., García García, M., \& Guardia González, S. (2005). La tutoría universitaria ante el proceso de armonización europea (R. d. Educación Ed. Vol. 337).

Hoaas, G. (2014). Study- and practice-period in Africa, for students of Early Childhood Education at Oslo University College. NERA Journal: A Journal for the Namibian Educational Research Association, 12(1), 104-120. 
Koester, J. (1988). New data on U.S. students abroad: Implications and orientation. In J. A. Mestenhauser, G. G. Marty, \& I. Steglitz (Eds.), Culture, learning, and the disciplines: Theory and practice in the cross-cultural orientation (p. 121). Washington, DC: National Association for Foreign Students Affairs.

Likert, R. (1932). A technique for the measurement of attitudes. Archives of Psychology 22 (140), pp.5 - 55.

Maiworm, F., \& Teichler, U. (1996). Study abroad and early career: Experiences of former ERASMUS students. Bristol: Jessica Kingsley.

Martín, A. (2012). Erasmus significa Europa. Tribuna Complutense. Retrieved from http://biblioteca.ucm.es/revcul/tribunacomplutense/70/art1129.php - .Vp-FWE32aUk

Meer, N., \& Modood, T. (2012). How does interculturalism contrast with multiculturalism? Journal of Intercultural Studies, 33(2), 175-196.

http://dx.doi.org/10.1080/07256868.2011.618266

Paige, R. M., Cohen, A. D., Kappeler, B., Chi, J. C., \& Lassgard, J. P. (2002). Maximizing study abroad: A student guide to strategies for language and culture learning and use. Minneapolis: University of Minnesota.

Papatsiba, V. (2005). Political and individual rationales of student mobility: A case-study of ERASMUS and a French regional scheme for studies abroad. European Journal of Education, 40 (2), 173-188.

http://dx.doi.org/10.1111/j.1465-3435.2004.00218.x

Parekh, B. C. (2002). Rethinking multiculturalism: Cultural diversity and political theory. Cambridge, MA: Harvard University Press.

Samovar, L. A., Porter, R. E., \& McDaniel, E. R. (2010). Communication between cultures (7th ed.). Boston, MA: Wadsworth/Cengage Learning.

Teekens, H. (Ed.) (2006). Internationalization at home: A global perspective. The Hague: Nuffic.

Teichler, U., \& Maiworm, F. (1997). The ERASMUS experience: Major findings of the ERASMUS Evaluation Research Project. Luxembourg: Office for Official Publications of the European Communities.

UNESCO. (1998). World Declaration on Higher Education for the Twenty First Century. Action and Vision. Retrieved from http://unesco.org/education/educprog/wche/declaration eng.htm

UNESCO. (2000). Education for all: 2000 assessment; Global synthesis. Retrieved from http://unesdoc.unesco.org/images/0012/001200/120058e.pdf 